\title{
Hubungan Kejadian Penyakit Pada Ovarium terhadap Terjadinya Infertilitas di Rumah Sakit Umum Daerah Haji Makassar tahun 2015
}

\author{
Hatijar \\ Sekolah Tinggi Ilmu Kesehatan Husada Mandiri Poso \\ Email: yjharsaja@gmail.com
}

\begin{abstract}
Background: Abnormalities / diseases of the ovary are manifestations of growth deviations and organ formation. Abnormalities / diseases of the ovary are closely related to women who have low fertility or experience infertility. Objective: to determine the relationship of Ovarian Disease Occurrence to the occurrence of Infertility in Haji Makassar General Hospital in 2015. Research Methods: This research is a quantitative type of research with descriptive analytic research type. Subjects were mothers who suffered from ovarian disease who were treated in the Gynecological Room of the Makassar Haji General Hospital as many as 52 people were treated in the obstetric room. The research sample was taken with purposive sampling technique totaling 37 respondents. Data were analyzed by univariate and bivariate using Chi-Square statistical test with a significance value of $\mathrm{P}$-value $95 \%(\mathrm{p}=0.05)$. Result: there is a relationship between disease in the ovary and infertility $(p=0,000)$. Conclusion: there is a relationship between disease in the ovary and infertility.
\end{abstract}

Keywords: ovarian disease, infertility

\begin{abstract}
Abstrak
Latar Belakang : Kelainan/ penyakit pada ovarium merupakan manifestasi penyimpangan pertumbuhan dan pembentukan organ tubuh. Kelainan/ Penyakit pada Ovarium erat hubungannya dengan wanita yang tingkat kesuburannya rendah atau mengalami infertilitas. Tujuan: untuk mengetahui Hubungan Kejadian Penyakit pada Ovarium terhadap terjadinya Infertilitas di Rumah Sakit Umum Daerah Haji Makassar tahun 2015. Metode Penelitian : Penelitian ini merupakan jenis deskriptif analitik. Subyek penelitian adalah ibu yang menderita penyakit pada ovarium yang di rawat di Ruang Ginekologi Rumah Sakit Umum Daerah Haji Makassar sebanyak 52 orang yang dirawat di ruang kebidanan. Sampel penelitian diambil dengan tehnik Purposive Sampling berjumlah 37 responden. Data dianalisis secara univariat dan bivariat menggunakan uji statistik Chi-Square dengan nilai signifikansi P-value 95\% $(p=0,05)$. Hasil : ada hubungan antara penyakit pada ovarium terhadap terjadinya infertilitas $(p=0,000)$. Kesimpulan: ada hubungan antara penyakit pada ovarium terhadap terjadinya infertilitas
\end{abstract}

Kata Kunci : penyakit ovarium, infertilitas 


\section{PENDAHULUAN}

Infertilitas adalah suatu keadaan dimana tidak memiliki anak setelah 1 tahun menjalani aktifitas seksual secara regular tanpa menggunakan teknik kontrasepsi (1). Kejadian infertilitas bukan hanya merupakan suatu masalah kesehatan, tetapi juga termasuk dalam suatu masalah sosial. Masalah infertilitas ini dapat mempengaruhi berbagai aspek kehidupan antara lain hubungan interpersonal, perkawinan dan sosial, serta dapat menyebabkan gangguan secara emosional dan psikologis dan dari semua pasangan yang aktif secara seksual, 12-15\% mengalami infertilitas (2).

Pada tahun 2010, infertilitas diperkirakan terjadi pada 48,5 juta pasangan di seluruh dunia. Wanita yang berumur 20-44 tahun yang ingin memiliki anak mengalami infertilitas primer sebesar $1,9 \%$ dan $10,5 \%$ wanita mengalami infertilitas sekunder). Pasangan suami istri yang mengalami gangguan kesuburan pada tingkat dunia mencapai $10-15 \%$, dari jumlah tersebut 90\% diketahui penyebabnya, sekitar 40\% diantaranya berasal dari faktor wanita. Dan di Indonesia pasangan infertil pada tahun 2013 adalah 50 juta pasangan atau 15-20\% dari seluruh pasangan yang ada (3).

Beberapa penyebab terjadinya infertilitas antara lain dari dari pihak yaitu masalah vagina yaitu vaginitis, servisitis, uterus, tuba dan masalah di ovarium yaitu kista ovarium. kista ovarium merupakan masalah kesehatan reproduksi yang dapat menyebabkan infertilitas (4). Kista ovarium merupakan suatu benjolan yang berada di ovarium yang dapat mengakibatkan pembesaran pada perut bagian bawah (5).

Angka kejadian kelainan/ penyakit pada ovarium di Indonesia pada tahun 2014 belum diketahui dengan pasti karena sistim pencatatan dan pelaporan yang belum akurat. Sebagai gambaran di Rumah Sakit Kanker Dharmis ditemukan berkisar 20 orang penderita kista ovarium, dimana hal ini erat hubungannya dengan wanita yang tingkat kesuburannya rendah atau infertilitas (6).

Di Sulawesi Selatan khususnya di Rumah Sakit seluruh wilayah Makassar ditemukan berkisar 50 orang penderita yaitu meninggal sekitar 30 orang dan masih menderita 20 orang. Kelainan/ Penyakit pada Ovarium erat hubungannya dengan wanita yang tingkat kesuburannya rendah atau infertilitas. Oleh karena tingginya angka kejadian penyakit pada ovarium dan kejadian 
ini merupakan masalah penting menyangkut kualitas kesehatan reproduksi wanita yang dalam kasus ini kebanyakan mengalami infertilitas.

\section{METODE}

Penelitian ini menggunakan deskriptif analitik dengan pendekatan cross sectional Study. dimana penelitian ini melihat hubungan variabel independen (Penyakit pada Ovarium) sebagai faktor resiko terhadap terjadinya Infertilitas sebagai variabel dependen. Populasi dalam penelitian ini yaitu Semua Ibu yang dirawat di Ruang Ginekologi Rumah Sakit Umum Daerah Haji Makassar sebanyak 157 Orang dengan tehknik sampel menggunakan purposive sampling dengan jumlah sampel sebesar 37 orang. Dan kriteria inklusi yaitu semua ibu yang menderita gangguan ovarium dan mengalami infertilitas. Data dianalisis dengan menggunakan uji statistic Chi-Square dengan nilai $\mathrm{P}<0,05$.

\section{HASIL}

Tabel 1 Gambaran Kejadian Penyakit Pada Ovarium di Rumah Sakit Umum Daerah Haji Makassar

\begin{tabular}{|c|c|c|}
\hline $\begin{array}{c}\text { Penyakit Pada } \\
\text { Ovarium }\end{array}$ & Frekuensi (N) & Persentase (\%) \\
\hline Kista Ovarium & 17 & 45,95 \\
Kanker Ovarium & 20 & 54,05 \\
\hline Jumlah & $\mathbf{3 7}$ & $\mathbf{1 0 0}$ \\
\hline
\end{tabular}




\section{Tabel 2}

Gambaran Kejadian Infertilitas Pada Penderita Penyakit Pada Ovarium di Rumah Sakit Umum Daerah Haji Makassar

\begin{tabular}{|c|c|c|}
\hline $\begin{array}{c}\text { Kejadian Penyakit Pada } \\
\text { Ovarium Dengan Infertilitas }\end{array}$ & Frekuensi (N) & Persentase (\%) \\
\hline & 15 & 40,54 \\
Infertilitas Primer & 22 & 59,46 \\
Infertilitas Sekunder & $\mathbf{3 7}$ & $\mathbf{1 0 0}$ \\
\hline Jumlah & & \\
\hline
\end{tabular}

Tabel 3

Pengaruh Penyakit Pada Ovarium Terhadap Terjadinya Infertilitas di Rumah Sakit Umum Daerah Haji Makassar

\begin{tabular}{|c|c|c|c|c|c|}
\hline \multirow{2}{*}{ Penyakit } & \multicolumn{2}{|c|}{ Infertilitas } & \multicolumn{2}{c|}{ TOTAL } & \multirow{2}{*}{ P-Value } \\
\cline { 2 - 5 } Pada Ovarium & Primer & Sekunder & n & $\%$ & \\
\hline Kista Ovarium & 14 & 3 & 17 & 45,95 & \multirow{2}{*}{0,000} \\
\hline Kanker Ovarium & 1 & 19 & 20 & 54,05 & \\
\hline JUMLAH & 15 & 22 & 37 & 100 & \\
\hline
\end{tabular}

Tabel 1. menunjukkan bahwa dari 37 orang yang menderita penyakit pada ovarium dengan infertilitas terdapat 17 orang $(45,95 \%)$ yang mengalami kista ovarium dan yang mengalami kanker ovarium sebanyak 20 orang $(54,05 \%)$.

tabel 2. menunjukkan dari $37 \mathrm{ibu}$ yang mengalami penyakit pada ovarium dengan infertilitas yang menjadi sampel menunjukkan bahwa persentase terbanyak adalah ibu yang mengalami infertilitas sekunder sebanyak 22 orang $(59,46 \%)$, kemudian ibu yang mengalami infertilitas primer sebanyak 15 orang $(40,54 \%)$.

Pada tabel 3. menunjukkan bahwa dari 37 sampel yang ada, yang mengalami infertilitas primer sebanyak 14 orang dan infertilitas sekunder sebanyak 3 orang pada 17 orang $(45,95 \%)$ penderita 
kista ovarium sedangkan pada 20 orang $(54,05 \%)$ penderita kanker ovarium yang mengalami infertilitas primer sebanyak 1 orang dan infertilitas sekunder sebanyak 19 orang.

Hasil uji statistic chi-square dengan menunjukkan nilai $\rho=0,000$ dimana $\rho<\alpha=0,05$, ini berarti ada hubungan antara penyakit pada ovarium terhadap terjadinya infertilitas.

\section{PEMBAHASAN}

Penyebab pasti penyakit pada ovarium belum diketahui. Namun, ada beberapa faktor resiko, antara lain tidak menikah, tidak punya atau sedikit anak, kebiasaan menggunakan talk/bedak tabur di daerah vagina, haid dini, menopause terlambat, terkena radiasi, serta faktor genetik. Sedangkan dampak yang timbul akibat penyakit pada ovarium adalah sulitnya terjadi pembuahan bahkan tidak memiliki anak/keturunan (infertilitas). Hal ini didukung oleh pernyataan Utami, (2012) yang menyatakan bahwa kejadian infertilitas disebabkan oleh kelainan yang terjadi pada wanita yang paling banyak ditemukan yaitu kelainan pada ovarium, yang diikuti oleh faktor tuba dan uterus.

Penelitian Ini sejalan dengan penelitian yang dilakukan oleh Indarwati, dkk (2017), dimana hasil penelitian menunjukkan bahwa terdapat pengaruh antara kelainan organ reproduksi dengan infertilitas wanita. Wanita yang memiliki kelainan organ reproduksi yang mencakup gangguan ovulasi, gangguan tuba dan pelvis serta gangguan uterus dimana sebagian besar mengalami infertilitas dibandingkan dengan wanita yang tidak memiliki kelainan organ reproduksi. (8)

Dalam konsensus penanganan infertilitas tahun 2013 pleh Himpunan Endokrinologi Reproduksi dan Fertilitas Indonesia (HIFERI), Perhimpunan Fertilisasi In Vitro Indonesia (PERFITRI), Ikatan Ahli Urologi Indonesia (IAUI), dan Perkum-pulan Obstetri dan Ginekologi Indonesia (POGI) menyebutkan bahwa faktor penyebab infertilitas pada wanita sebagian besar disebabkan oleh kelainan organ reproduksi yang terdiri dari gangguan ovulasi (PCOS, gangguan pada siklus hais, insu-fisiensi primer), gangguan tuba dan pelvis (infeksi maupun endometriosis), dan gangguan uterus (mioma submukosum, polip endometrium, leiomyomas, dan sindrom asherman). (9).

Infertilitas adalah ketidakmampuan untuk hamil setelah sekurang-kurangnya satu tahun berhubungan seksual sedikitnya empat kali seminggu tanpa kontrasepsi. Infertilitas 
dikategorikan menjadi dua yaitu infertilitas primer dan infertilitas sekunder. Pengertian infertilitas primer menurut WHO adalah ketidakmampuan untuk memperoleh kehamilan setelah dua tahun melakukan koitus secara teratur tanpa menggunakan alat kontrasepsi. Sedangkan Infertilitas sekunder diartikan sebagai ketidakmampuan untuk memperoleh kehamilan setelah sebelumnya sudah ada riwayat hamil. Pada penelitian ini kebanyakan pasangan infertil merupakan jenis infertilitas sekunder. (10)

Dalam penelitian ini ditemukan adanya pengaruh kista ovarium terhadap kejadian infertilitas. Penelitian ini sejalan dengan penelitian yang dilakukan oleh Trisnawati (2015) menemukan adanya hubungan antara pembesaran kista ovarium dengan infertilitas (11). Kista ovarium merupakan suatu pembesaran dari indung telur yang berisi cairan dimana isi dari kista tersebut dapat berupa cairan jernih atau berisi struktur yang lebih kental, bertekstur dan kompleks. Dalam proses perkembangannya, kista ovarium akan mengalami suatu pembesaran bahkan pecah dari pembesaran tersebut. Pembesaran dari kista ovarium tersebut kemudian akan menyebabkan penebalan dinding ovarium dan menghalangi proses ovulasi, selain itu kista ovarium yang pecah akibat pembesaran tersebut akan menyebabkan suatu perlengketan di dalam tuba fallopi akibat pemadatan cairan yang berada di dalam kista (12). Hal ini yang dapat menyebabkan jalan pertemuan antara sperma dan sel telur menjadi tertutup. (13).

Dalam penelitian ini juga ditemukan responden yang menderita kanker ovarium mengalami infertilitas. dari beberapa penelitian yang telah dilakukan menyebutkan bahwa faktor risiko kanker ovarium meliputi ovulasi yang tidak terputus atau disebut dengan infertilitas atau tidak pernah hamil ataupun nulipara (14). Penelitian yang dilakukan oleh Maryani, dkk (2013) menemukan bahwa wanita yang pernah mengalami infertilitas menjadi faktor penyebab yang signifikan terhadap kejadian kanker ovarium (nilai $\mathrm{OR}=2.09$ ) dibandingkan tidak pernah mengalami infertilitas. (15) 


\section{KESIMPULAN}

Berdasarkan hasil penelitian yang diperoleh maka dapat disimpulkan a). gangguan penyakit pada ovarium yang dialami responden sebagian besar adalah kanker ovarium. b) kejadian infertilitas yang dialami sebagian besar responden adalah infertilitas sekunder. c). sebagian besar responden mengalami bahwa ada pengaruh antara gangguan/ penyakit pada ovarium terhadap terjadinya infertilitas.

\section{DAFTAR PUSTAKA}

1. Gurunath S, Pandian Z, Richard AR, Bhatthacharya S. Defining infertility a systemic review of prevalence studies. 2011

2. Parekattil SJ, Agarwal A (eds). Male infertility: Clinical approaches, andrology, ART, \& antioxidants. New York: Springer. 2012.

3. Riskesdas. Riset kesehatan dasar. Jakarta: Kementrian Kesehatan RI. 2013

4. Manuaba, I. B. G. Memahami kesehatan reproduksi wanita (2 ed.). Jakarta: EGC. 2009.

5. Prawirohardjo, Sarwono. 2014. Ilmu Kebidanan Sarwono Prawirohardjo. Jakarta: PT Bina Pustaka Sarwono Prawirohardjo

6. Suprida. Hubungan Antara Pendidikan dan Umur Ibu dengan Pemilihan Kontrasepsi Implan di Bidan Praktik Mandiri Rachmi Palembang Tahun 2013. Poltekkes Kemenkes Palembang. 2013

7. Utami, T. Faktor Penyebab Infertilitas Primer di Klinik Infertilitas Permata Hati RSUP dr. Sardjito Periode 1 September 2011 - 31 Desember 2011. Yogyakarta: Medical Faculty Univer-sitas Islam Indonesia. 2012

8. Indarwati, Ika., Hastuti, Uki Retno Budi., Dewi, Yulia Lanti Retno. Analysis of Factors Influencing Female Infertility. Journal of Maternal and Child Health. 2017

9. HIFERI. Konsensus Penanganan Infertilitas. Himpunan Endokrinologi Reproduksi dan fertilitas Indonesia. 2013

10. Prawirohardjo, S. Infertilitas. Dalam : Mohammad, A., A. Baziad, P. Prabowo ( Editor). Ilmu Kandungan (halaman 424-434). PT Bina Pustaka Sarwono Prawirohardjo. Jakarta, Indonesia. 2011

11. Trisnawati, Yuli. Analisis Kesehatan Reproduksi Wanita Ditinjau Dari Riwayat Kesehatan Reproduksi Terhadap Infertilitas Di Rs Margono Soekardjo Tahun 2015. Akademi Kebidanan YLPP Purwokerto. 2015

12. Price dan Wilson. Patofisiologi. Jakarta: EGC. 2006.

13. Brooker, C. Hipertensi ensiklopedia keperawatan. Jakarta: EGC. 2008

14. Kazeuroni, Niloufar Neely. Family History of Breast Cancer as a Determinant of the Risk of Developing Endometrial and Ovarian Cancers: A Nationwide Cohort Study. Disertasi. ProQuest Information and Learning Company. 2002 
15. Maryani, Dini.,Adisasmita, Asri C., Dwipoyono, Bambang. Hubungan Riwayat Reproduksi, Penggunaan Hormon, dan Riwayat Kanker pada Keluarga dengan Kanker Ovarium pada Pasien RS Kanker Dharmais Jakarta Tahun 2013. Fakultas Kesehatan Masyarakat Universitas Indonesia. 2013 